Hamad, A.A., Tuzlukaya, S., \& Kırkbeşoğlu, E. (2019). The effect of social capital on operational performance: research in banking sector in Erbil. Copernican Journal of Finance \& Accounting, 8(1), 103-124. http://dx.doi.org/10.12775/CJFA.2019.004

\author{
Ahmed Abdulqader Hamad* \\ Ministry of Finance in Erbil, CFU International Company \\ ŞULE TUZLUKAYA ${ }^{* *}$ \\ Atılım University \\ ERDEM KIRKBeşoĞLu** \\ Başkent University
}

\title{
THE EFFECT OF SOCIAL CAPITAL \\ ON OPERATIONAL PERFORMANCE: \\ RESEARCH IN BANKING SECTOR IN ERBIL
}

Keywords: social capital, dimensions of social capital, operational performance development, Erbil.

J E L Classification: G21, 01, A1, C0.

Date of submission: April 25, 2019; date of acceptance: June 1, 2019.

* Contact information: ahmed_xamena@yahoo.com, Ministry of Finance, Erbil, Iraq, phone: 00964750 4649002, Assistant Manager, CFU International Company: Vice Manager; ORCID ID: https://orcid.org/0000-0002-4252-318X.

${ }^{* *}$ Contact information: correspondent author, sule.tuzlukaya@atilim.edu.tr, Atılım University, Faculty of Management, Department of Management, Incek, Ankara, Turkey, phone: +90 312 5868612; ORCID ID: https://orcid.org/0000-0001-8244-6396.

*** Contact information: erdemk@baskent.edu.tr, Baskent University, Baglica Kampusu Eskisehir Yolu 20. km, Faculty of Commercial Sciences, Baglica, Ankara, Turkey, phone: +90 312 2466666; ORCID ID: https://orcid.org/0000-0002-6781-9753.

This study is a part of the first author's unpublished master thesis. 


\begin{abstract}
Social capital as a field of study has grown with many contributions from different fields. Yet, the gap within the literature regarding different contexts has inspired researchers to look for further explanations about social capital and its dimensions. Therefore, this paper aims to provide insight into the impact of social capital as a specific factor to develop commercial banks' operational performance in Erbil City, Iraq. To achieve this, a quantitative research is carried out, findings pointing to positive significant relationships between the dimensions of social capital as relational, structural and cognitive capital and operational performance development. Additionally, according to results, social capital plays a vital role in commercial banks' stability and development of operational performance.
\end{abstract}

\title{
INTRODUCTION
}

There is an extensive and vigorous body of research regarding social capital (Lee, 2009; Carolis. Litzky \& Eddleston, 2009; Parker, Halgin \& Borgatti, 2016; Portes, 1998; Andrews, 2010; Li, Lin \& Arya, 2008; Light \& Dana, 2013; Manning, 2010). Social capital is a vital asset of organizations, used to generate value for them by means of an accumulation of relational capital, structural capital and cognitive capital (Burt, 1997; Burt, 2004; Putnam, 1995; Bourdieu, 1985; Portes, 1998). As a field of study, social capital has received attention from different disciplines such as management, political sciences and sociology and thanks to analyses at different levels (Adler \& Kwon, 2002). According to Gupta, Raman and Shang (2018, p. 102), "Economists have long recognized that a key component of social capital is essential to economic success in society". Similarly, Lin (1999) refers to social capital's vital role by stating the importance of reaching and mobilizing specific resources. Other researchers within the field, such as Inkpen and Tsang (2005, p. 151) state that social capital is "the aggregate of resources embedded within, available through and derived from the network of relationships possessed by an individual or organization". According to Lee (2017, p. 39) "It is inherently fuzzy, multifaceted, difficult to operationalize and suffers from measurement challenges". The common point of all studies as Gargiulo and Benassi (2000) claim is that social capital can be recognized as the overall tangible and intangible resources that might be gained through social exchanges. Investments and accumulations in this way can be based on various actors' interests or benefits and materialized as a result of different motivations.

Studies both on social capital and its dimensions are abundant in the literature (Portes, 1998; Putnam, 1995; Seibert, Kraimer \& Liden, 2001; Packalen, 2007). However, those investigating the relationship between social capital 
and performance within different contexts are rather few. In light of this gap, the present paper, by considering the above-mentioned background and growing attention of social capital, aims to shed light on the effect of the proper investment and practice of social capital in controlling the operational performance of commercial banks. In detail, the purpose of this study is to investigate the effect of social capital on the operational performance development of commercial banks in Erbil. As stated before, social capital is an imperceptible asset of the organizations and, is used to generate a value for organizations through establishing relational, structural and cognitive capital. Social capital, which represents the knowledge and creativity of the bank's staff, to provide high value and competitive advantage, as social capital is one of the most vital pillars of superiority for banks in a world of intense competition.

At the organizational unit of analyses, the existence of social capital is paramount in terms of survival; it provides many advantages, particularly performance-based. In general, the term performance is the transformation of inputs into ready products or services. Furthermore, it is explained as one of the functions of any organization. Recently, researchers have come up with high performance in terms of relation and through knowledge-sharing (Clark, 1991). According to Sanders (2008), operational performance makes a strategic contribution to organizations by providing long-term benefits to stakeholders such as entering a new market, innovating products, and competing in different environments. Social capital has been described as an important resource that can create value for organizations through established linkages, which, in terms, also provide competitive advantage (Cary, 2011; Koka, 2008; Maurer, Bartsch \& Ebers, 2011). Many scholars have pointed out that social capital allows for changes in operational performance by facilitating competitive advantage and sustainability (Kale, Singh \& Perlmutter, 2000; Doz, 1996). From the perspective of management, organizational performance is highly related to profitability (Koufopoulos, Zoumbos, Argyropoulou \& Motwani, 2008).

In this study, a quantitative research is carried out to collect the necessary data. The research sample comprises from commercial banks all operating in Erbil, and the data is collected using a questionnaire. Accordingly, the study investigates the relationship between social capital dimensions and operational performance development.

The structure of the paper is as follows: The upcoming section presents the background related to social capital theory, focusing on the historical background and evolution of the concept. In the third section, the dimensions of 
social capital and operational performance concepts are introduced and explained. The research methodology, analysis, and findings are discussed in the fourth section. Finally, the conclusion sums up the main findings. An important contribution of this study is that it provides a comprehensive explanation as to the dimensions of social capital and their relationship with operational performance, in particular within commercial banks.

\section{LITERATURE REVIEW}

\section{Social capital}

Bourdieu (1985) classifies capital as material and physical. In this respect, despite its constant and numerous appearances in the literature, the term 'social capital' remains a vague concept in theoretical terms. One of the broadest and most commonly accepted definitions of social capital was introduced by Coleman (1990), through the comparison of physical and social capital as: "If physical capital is wholly tangible, being embodied in observable material form, and human capital is less tangible, being embodied in the skills and knowledge acquired by an individual, social capital is less intangible yet, for it exists in the relations among persons" (Coleman, 1990, pp. 100-101). In the literature, there are different approaches to social capital most of which mainly focus on the strong social capital of actors and their privileges.

Social capital can appear at all levels of the organization and make a relation between individuals, groups, and society (Svendsen, 2006). According to Coleman (1990), social capital is considered as in the form of factors such as obligation, expectation, channel sources and effective outcomes. Further, it may be considered as a kind of a tool that allows the organization to generate profits from different activities (Hughes, 2011). According to Silkoset (2013), social capital is also an indicator for individuals as it is a useful source for improving individual relations. Apart from this, it allows the organizational members to share information through established relationships with other organizations - a process which can be referred to as creativity (Reagans \& Zuckerman, 2001; Maurer et al., 2011). It has been described as an important resource in the organization that can add value and innovation into the firms' activities. Scholars point out that social capital makes changes in the operational performance of firms (Burt, 2010). Nahapiet and Ghoshal (1998) investigated social capital and proposed three dimensions, namely relational (trust, obligation, and identifica- 
tion), structural (density, configuration, and information-sharing) and cognitive (mission and vision, general language, sharing codes, and understanding).

\subsection{Dimensions of Social Capital}

Social capital occurs at many different levels and perceived differently within an organization due to different factors. As a whole, however, it is considered as a reliable tool to establish trust in network relationships. According to study by Nahaphiet and Ghoshal (1998), social capital has three dimensions in terms of the level of individuals and groups in an organization and their links to social networks; these are relational, structural, and cognitive. In business and management literature, there are many empirical studies in terms of these dimensions (Brett, Shapiro \& Lytle, 1998; Gargiulo \& Benassi, 2000; Hatzakis, Lycett, Macredie \& Martin, 2005; Tsai \& Ghoshal, 1998). Lee (2009, p. 254) underlines the importance of these aspects by stating "structural, relational and cognitive dimensions combine to minimize inefficiencies in the exchange of information, knowledge, and resources".

The first dimension, which is relational, relates to trust, expectations, and duties, to shows the quality of employees and builds a suitable environment to establish relationships. Structural, the second dimension refers to the form of the organizational, the intensity of relations among employees. The last dimension, cognitive, is based on the general language, understanding, knowledge, mission, vision, goal and value of the organization (Nahapiet \& Ghoshal, 1998). These three dimensions are necessary for developing social capital and accessing vital resources (Adler \& Kwon, 2002; Totterman \& Sten, 2005).

\section{RELATIONAL CAPITAL}

In what follows, we will look at each dimension in detail. This aspect of social capital is mainly based on trust and considers strong ties. It can be described as the exchanges between actors that establish an organizational system. According to Nahapiet and Ghoshal (1998), the history of interaction among actors is an element that is shaped as a result of personal relationships. Additionally, Granovetter (1992) suggests that this dimension may be considered as an improved version of the relationship among people established via historical events. In short, it refers to normative conditions that guide individual actors' relations (Lee, 2009). Other researchers showed that trust maintains lengthy 
relationships between stakeholders and organizations (Helper, 1991). In other words, it makes the firm and those dealing with the work together for longer periods of time. In this way, operations among organizations based on trust can achieve advantages with no regret for possible consequences (Parkhe, 1993; Ferris, Javakhadze \& Rajkovic, 2017).

\section{Structural capital}

Structural dimension refers to the linkage between the actors or units in the organization, focusing on the actor's connection with the others from different ranks of the organization to measure the strength of the ties between the actors. In short, it reflects on "the presence or absence of network ties" (Nahapiet \& Ghoshal, 1998, p. 244). Structural capital is explained as a network configuration and/or information sharing to show density, connectivity, and hierarchy between the actors and organizations (Nahapiet \& Ghoshal, 1998; Lee, 2009). Researchers argue that spreading the information of organizational target through social capital may inspire appropriate practices among organizations, explain the accumulation of tacit knowledge (Bessant, 2003), and may provide stability to individuals and groups (Inkpen \& Tsang, 2005). In turn, stability is the significant principle for an organization to maintain high performance.

\section{Cognitive capital}

The third dimension, cognitive capital, according to Nahapiet and Ghoshal (1998), reflects the already shared mission and vision of the organization by its members. The fundamental elements of cognitive capital, as described by Inkpen and Tsang (2005), are goal and culture. Accordingly, the members of the organization develop a common understanding in terms of these goals and, as such try to achieve mutual outcomes. Also, it serves as a channel for sharing and transmitting information and values (Tsai \& Ghoshal, 1998). Fukuyama (1997) points out to the importance of sharing informal values and/or norms that allow cooperation among members. Overall, it is the dimension that represents the ability to communicate as well as accuracy in perception (Inkpen \&Tsang, 2005; Adler \& Kwon, 2002). 


\section{Organizational Operational performance}

Organizational performance is one of the key concepts in business and management literature. Organizations put all their efforts into reaching a high level of business performance. Operational performance is mainly related to competitive advantage and can be defined in terms of cost, quality, delivery, flexibility and innovation (Cousins, 2006; Lawson, 2008; Ward, 1998). Additionally, as Sanders (2008) suggests, performance provides significant benefits to both suppliers and buyers, by attaching value in terms of fitting their outcomes in terms of adapting organizational goals with the demand of customers. According to Cary (2011), social capital affects positively the operational performance in terms of controlling costs and facilitating innovation. As Kleinbaum and Tushman (2004) and Lee (2009) suggest, there is a growing and interesting body of research that focuses on the relationship between social capital and firm performance. Burt (2000) is considered one of the earliest contributors regarding the relationship between social capital and performance. However, other very important studies also exist in the literature (Lee, 2004).

In Erbil, the status of the banking sector is in the process of development for now. For this reason, the study of this nature and with these goals can be particularly important for this region, which has remained out of focus in the literature. Social capital becomes an important asset for organizations such as banks in an era of globalization. Accordingly, the need for commercial banks to operate in Erbil using such resources and abiding by such values is the challenge this region will have to face to be successful in the international markets.

\section{Relating Social capital to Operational Performance}

Some researchers suggest that trust is the main factor to increase the relationship between employees and connect an organization with others (Helper, 1991; Sako \& Helper, 1998). In the social capital literature, it is argued that cooperation among organizations can also reduce the incidents of opportunism (Parkhe, 1993). When trust is achieved, employees and partners can share experience and knowledge, provide a system for sharing information, and last but not least, improve organizational performance (Doz, 1996). Kale et al. (2000) argue that relational capital eliminates certain risks organization face when making investments in order to achieve operational advantages. Furthermore, it keeps costs low since there is no further requirement for monitoring due to 
the established trust among members (Kale et al., 2000). As a result, it can be concluded that cooperation within the organization and/or other organizations definitely improves performance and provides stability. Therefore, the first hypothesis of this study is as follows:

H1: There is a positive relationship between the relational capital and the operational performance of commercial banks operating in Erbil city.

Structural capital is defined as a kind of direct involvement, mainly that employees in the organization can be considered as the prime factor for developing operational performance. Employees are very crucial in this sense since they transfer and exchange tacit knowledge related to the organization. Therefore, structural capital is important not only in terms of collecting and spreading information, proliferation of implicit understanding related to the subject inside the organization itself (Lawson, 2008; Moran, 2005). Sharing information and knowledge among employees reinforces better outcomes and reduced costs. According to Lawson (2008) building up structural capital may also help to achieve high performance. Such capital, once established, helps to gain various benefits and competitive advantages (Lawson, 2008). Based on this, the second hypothesis can be proposed:

H2: There is a positive relationship between the structural capital and the operational performance of commercial banks operating in Erbil city.

As a third dimension, cognitive capital, is also closely related to operational performance. Nahapiet and Ghoshal (1998) argue that cognitive capital appears in the general language, representation, and interpretations. Once an organization is involved in various tasks, it may concentrate on necessary activities and share a general language, which is generated from a cognitive background to improve its operational performance (Handfield \& Nichols, 1999). Furthermore, when goals and visions are shared among employees, better outcomes and improvements and are expected, thus it leads to achieving bigger development in terms of organizational performance (Krause, Handfield \& Tyler, 2007). Also, the creation of good internal values through cognitive capital allows for improving innovation and generating new services and/or ideas. Following this reasoning, a third hypothesis is proposed:

H3: There is a positive relationship between the cognitive capital and the operational performance of commercial banks operating in Erbil city. 


\section{THE RESEARCH METHODOLOGY AND THE COURSE OF THE RESEARCH PROCESS}

\section{Research Design}

The primary aim of this study is to investigate the effect of social capital and its dimensions on organizations' operational performance. In this study, a quantitative research approach is carried out and the survey design is applied for data collection.

\section{Sample}

The survey is distributed through the bank senior managers, middle managers and administrative staff who are mainly responsible for the performance and related services offered by the establishment. Thirty-six different banks operate in Erbil, out of which 24 banks accepted to participate in the present study. Of the total 140 employees that received the questionnaire, 111 respondents returned the questionnaires. The survey adapted in this research is based on convenience sampling, indicating a response rate of $\% 79$.

\section{Methods of Data Collection}

For the purpose of the study, a survey was implemented for data collection which included dimensions of social capital and operational performance. The survey consists of 25 items to be scored on a 1-5 Likert scale. The first section with five questions as to gender, age, academic degree, position in the bank, and overall job experience; the second section is related to the scale for social capital (Tantardini \& Kroll, 2015); finally, the third section contained items of operational performance (Krause et al., 2007). As two different scales were implemented for this study, necessary information regarding to scales are as follows; Social capital scale contained 16 items. The items for each dimension of the social capital is composed of 5 items for relational, 5 items for structural and 6 items for cognitive capital, respectively. Besides, operational performance items are contained 9 items.

The survey that is designed for data collection the respondents are informed about the purpose of the study. Additionally, within the consent form also, the respondents are reminded in terms of the importance of the truthfulness of 
the answers. Finally, the consent form is also considered and informed the respondents that any personal information provided will remain secret. Accordingly, in the data collection step the necessary checks have been completed. After the data collection, before the data analysis step, essentially the researchers checked the data set also for the potential errors. So within this stage, the data is first checked in terms of outliers, minimum and maximum values, and also valid and missing cases.

\section{Reliability and Validity}

As shown in table 1 , the survey questionnaire reliability was tested to ensure the quality of the collected data. For the purpose of this study, Cronbach's alpha was administrated to test the stability of the scale by determining how accurate the items are measured yielding $0.881,0.806$ and 0.782 for the social dimensions, respectively. The operational performance development was 0.712 , which shows a degree of internal stability in the total set of objects of the survey. Therefore, the survey contains extremely reliable items.

Table 1. Reliability Statistics

\begin{tabular}{|l|c|c|c|c|}
\hline \hline \multicolumn{1}{|c|}{ Variables } & Cronbach's Alpha & No. of Items & N & \% \\
\hline \hline Relational Capital & $\mathbf{0 . 8 8 1}$ & 5 & 111 & 100.0 \\
\hline Structural Capital & $\mathbf{0 . 8 0 6}$ & 5 & 111 & 100.0 \\
\hline Cognitive Capital & $\mathbf{0 . 7 8 2}$ & 6 & 111 & 100.0 \\
\hline $\begin{array}{l}\text { Operational Perfor- } \\
\text { mance Development }\end{array}$ & $\mathbf{0 . 7 1 2}$ & 9 & & 111 \\
\hline \hline
\end{tabular}

S o u r c e : developed by authors.

\section{Construct Validity}

According to results of construct validity as shown in table 2, concerning the significance in relationships among variables, researchers conventionally test these relationships through correlation matrix and consider those producing a P-value below 0.05 to be significant. 
11 The efFect of social CAPItAL on operational PERFormance...

Table 2. Correlation Matrix between items and factors

\begin{tabular}{|c|c|c|c|c|}
\hline Factors & $\begin{array}{c}\text { Relational } \\
\text { Capital }\end{array}$ & $\begin{array}{c}\text { Structural } \\
\text { Capital }\end{array}$ & $\begin{array}{c}\text { Cognitive } \\
\text { Capital }\end{array}$ & $\begin{array}{l}\text { Operational } \\
\text { Performance }\end{array}$ \\
\hline $\mathrm{x} 1$ & $\begin{array}{c}1.000^{* *} \\
.\end{array}$ & & & \\
\hline$x 2$ & $\begin{array}{l}.759 * * \\
.000\end{array}$ & & & \\
\hline$x 3$ & $\begin{array}{l}.466 * * \\
.000\end{array}$ & & & \\
\hline $\mathrm{X} 4$ & $\begin{array}{l}.481^{* *} \\
.000\end{array}$ & & & \\
\hline X5 & $\begin{array}{l}.420 * * \\
.000\end{array}$ & & & \\
\hline x6 & & 1.000 & & \\
\hline$x 7$ & & $\begin{array}{l}.366 * * \\
.000\end{array}$ & & \\
\hline X8 & & $\begin{array}{l}.374 * * \\
.000\end{array}$ & & \\
\hline x9 & & $\begin{array}{l}.412 * * \\
.000\end{array}$ & & \\
\hline $\mathrm{x} 10$ & & $\begin{array}{l}.447^{* *} \\
.000\end{array}$ & & \\
\hline $\mathrm{X} 11$ & & & $1.000^{* *}$ & \\
\hline $\mathrm{x} 12$ & & & $\begin{array}{l}.219^{*} \\
.021\end{array}$ & \\
\hline $\mathrm{x} 13$ & & & $\begin{array}{l}.251^{* *} \\
.008\end{array}$ & \\
\hline X14 & & & $\begin{array}{l}.240^{*} \\
.011\end{array}$ & \\
\hline X15 & & & $\begin{array}{l}.423 * * \\
.000\end{array}$ & \\
\hline $\mathrm{X} 16$ & & & $\begin{array}{c}.253^{* *} \\
.007\end{array}$ & \\
\hline Y1 & & & & $1.000^{* *}$ \\
\hline Y2 & & & & $\begin{array}{l}.179 \\
.061\end{array}$ \\
\hline Y3 & & & & $\begin{array}{l}.823 * * \\
.000\end{array}$ \\
\hline
\end{tabular}


Table 2. Correlation Matrix...

\begin{tabular}{|l|l|l|l|c|}
\hline \hline \multicolumn{1}{|c|}{ Factors } & $\begin{array}{c}\text { Relational } \\
\text { Capital }\end{array}$ & $\begin{array}{c}\text { Structural } \\
\text { Capital }\end{array}$ & $\begin{array}{c}\text { Cognitive } \\
\text { Capital }\end{array}$ & $\begin{array}{c}\text { Operational } \\
\text { Performance }\end{array}$ \\
\hline \hline Y4 & & & & $.267^{* *}$ \\
& & & & .005 \\
\hline Y5 & & & & $.310^{* *}$ \\
& & & & .001 \\
\hline Y6 & & & & .151 \\
\hline Y7 & & & & .115 \\
\hline Y8 & & & & $.353^{* *}$ \\
& & & & .000 \\
\hline Y9 & & & & $.268^{* *}$ \\
& & & & .005 \\
\hline
\end{tabular}

${ }^{* *}$ Correlation is significant at the 0.01 level (2-tailed).

${ }^{*}$ Correlation is significant at the 0.05 level (2-tailed).

c. Listwise $\mathrm{N}=111$.

S o u r c e : developed by authors.

As seen in table 2, all the relational capital items as the first social capital's dimension were correlated and significant $(\mathrm{p}<0.01)$; so $\mathrm{X}_{1}$ strongly correlated with itself, and for the other two social capital dimensions (structural and cognitive), almost all items positively correlated with each other ( $\mathrm{p}<0.01$ and $\mathrm{p}<0.05) . \mathrm{X}_{6}, \mathrm{X}_{11}$ as the first items of the two components, strongly and positively correlated to themselves. Additionally, most operational performance items were significant $(p<0.01)$, except $Y_{2}$ and $Y_{6}(p>0.05)$. However, $Y_{1}$ strongly correlated to itself. Hence, this means there is a high level correlation among questionnaire items and factors.

\section{Data Analysis and Results}

SPSS 24 package proram was used to analyze the data in this study. Parametric statistical analysis was used to examine the proposed study hypotheses. Descriptive statistics were used to quantitatively define the significant features of the variables using mean and, standard deviations and to find out the rate of the importance of the variables. In table 3, respondents' characteristic is given. 
11. The efFect of social Capital on operational performance...

Table 3. Descriptive Statistics of the Respondents

\begin{tabular}{|c|c|c|c|}
\hline Valid & Demographics & Frequency & Percentage \\
\hline \multirow{2}{*}{ Gender } & Male & 54 & $48.6 \%$ \\
\hline & Female & 57 & $51.4 \%$ \\
\hline \multicolumn{2}{|l|}{ Total } & 111 & $100.0 \%$ \\
\hline \multirow{4}{*}{ Age Groups } & $25-35$ & 36 & $32.4 \%$ \\
\hline & $36-45$ & 47 & $42.3 \%$ \\
\hline & $46-55$ & 20 & $18.0 \%$ \\
\hline & 56 and above & 8 & $7.2 \%$ \\
\hline \multicolumn{2}{|l|}{ Total } & 111 & $100.0 \%$ \\
\hline \multirow{3}{*}{ Academic Degree } & Bachelor & 95 & $85.6 \%$ \\
\hline & Master Degree & 15 & $13.5 \%$ \\
\hline & Ph.D. & 1 & $0.9 \%$ \\
\hline \multicolumn{2}{|l|}{ Total } & 111 & $100.0 \%$ \\
\hline \multirow{3}{*}{ Position in the bank } & Senior Manager & 9 & $8.1 \%$ \\
\hline & Middle Manager & 49 & $44.1 \%$ \\
\hline & Administrative staff & 53 & $47.7 \%$ \\
\hline \multicolumn{2}{|l|}{ Total } & 111 & $100.0 \%$ \\
\hline \multirow[t]{4}{*}{ Overall job experience } & $1-5$ & 34 & $30.6 \%$ \\
\hline & $6-10$ & 33 & $29.7 \%$ \\
\hline & $11-15$ & 32 & $28.8 \%$ \\
\hline & $16-20$ & 12 & $10.8 \%$ \\
\hline \multicolumn{2}{|l|}{ Total } & 111 & $100.0 \%$ \\
\hline
\end{tabular}

S o u r c e : developed by authors.

In the sample, it is observed that $51.4 \%$ of the total respondents were female, while 48.6\% were male. Majority of the participants were aged 36-45. $85.6 \%$ of the respondents were Bachelor Degree holders. Besides, most of the respondents are at Middle Management level. Most of them have worked for about $1-5$ years in the bank. 


\section{Descriptive Statistics of the Study Variables}

The descriptive statistics of the variables are given in Table 4. According to results appear for descriptive statistics mean and standard deviation related to the independent variable and social capital scores 4.222 and 0.5156 , respectively. This mean that $84.4 \%$ of the entire respondents stated that social capital is significant as an independent variable with only $15.6 \%$ specifying that this variable is not important.

Table 4. Descriptive Statistics of the Variables and Dimensions

\begin{tabular}{|l|c|c|c|c|c|c|}
\hline \hline \multirow{2}{*}{ Variables and dimensions } & \multirow{2}{*}{ Items } & N & \multicolumn{4}{|c|}{ The rate of the Agreement } \\
\cline { 5 - 7 } & & & Mean & Std. Deviation & Agree & Disagree \\
\hline \hline Social Capital & 16 & 111 & 4.2224 & .51564 & $84.4 \%$ & $15.6 \%$ \\
\hline Relational Capital & 5 & 111 & 4.2865 & .62121 & $85.7 \%$ & $14.3 \%$ \\
\hline Structural Capital & 5 & 111 & 4.2036 & .56824 & $84 \%$ & $16 \%$ \\
\hline Cognitive Capital & 6 & 111 & 4.1847 & .54093 & $83.6 \%$ & $16.4 \%$ \\
\hline Operational performance & 9 & 111 & 3.9069 & .47391 & $78.1 \%$ & $21.9 \%$ \\
\hline \hline
\end{tabular}

S o u r c e : developed by authors.

From the same table, it can be seen that the mean scores of the relational, structural and cognitive capitals are 4.286, 4.203 and 4.184 respectively, and that standard deviation scores are $0.6212,0.568$, and 0.540 respectively. Although $85.7 \%, 84 \%$, and $83.6 \%$, respectively of the total responses indicated that commercial banks' relational, structural and cognitive capitals are important. Only, $14.3 \%, 16 \%$ and $16.4 \%$ specified that these dimensions are not important. As seen in the above table, the mean and standard deviation scores for operational performance development were 3.906 and 0.473 , respectively, and $78.1 \%$ of the all responses stated that operational performance development was important, and $21.9 \%$ of the did not agree with this.

Consequently, the results indicate that all the dimensions of social capital impact operational performance development of these commercial banks. Hence, the variables relational and structural capitals, respectively, are the most important features affecting operational performance development with 
$85.7 \%$ and $84 \%$ agreement. This is while cognitive capital scored the lowest important influence with a rate of $83.6 \%$.

\section{Correlation Matrix of Variables}

As revealed in table 5 , the correlation matrix tests clarify that all study variables correlated with one another where $(\mathrm{p}<0.05)$. However, the social capital significantly correlated with the operational performance ( $\mathrm{r}=0.491 ; \mathrm{p}<0.05)$. Relational, structural, and cognitive capitals positively correlated with operational performance. Furthermore, relational capital, structural capital, and cognitive capital, through $\mathrm{r}=0.595,0.590$ and 0.394 respectively, have strong positive correlations with operational performance, where a p-value of 0.000 , 0.000 and 0.000 respectively, is that less than 0.05 . Therefore, the hypotheses $\mathrm{H}_{1}, \mathrm{H}_{2}$, and $\mathrm{H}_{3}$ are accepted.

Table 5. Correlation Matrix Between Variables

\begin{tabular}{|c|c|c|c|c|c|c|c|}
\hline & & & Social Capital & $\begin{array}{c}\text { Relational } \\
\text { Capital }\end{array}$ & $\begin{array}{c}\text { Structural } \\
\text { Capital }\end{array}$ & $\begin{array}{c}\text { Cognitive } \\
\text { Capital }\end{array}$ & $\begin{array}{l}\text { Operational } \\
\text { performance }\end{array}$ \\
\hline \multirow{10}{*}{ 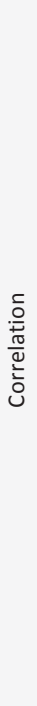 } & \multirow[t]{2}{*}{$\begin{array}{l}\text { Social } \\
\text { Capital }\end{array}$} & $\begin{array}{l}\text { Correlation } \\
\text { Coefficient }\end{array}$ & & $.828^{* *}$ & $.853^{* *}$ & $.879^{* *}$ & $.491^{* *}$ \\
\hline & & Sig. (2-tailed) & & .000 & .000 & .000 & .000 \\
\hline & \multirow[t]{2}{*}{$\begin{array}{l}\text { Relational } \\
\text { Capital }\end{array}$} & $\begin{array}{l}\text { Correlation } \\
\text { Coefficient }\end{array}$ & & & $.595^{* *}$ & $.590^{* *}$ & $.394^{* *}$ \\
\hline & & Sig. (2-tailed) & & & .000 & .000 & .000 \\
\hline & \multirow[t]{2}{*}{$\begin{array}{l}\text { Structural } \\
\text { Capital }\end{array}$} & $\begin{array}{l}\text { Correlation } \\
\text { Coefficient }\end{array}$ & & & & $.633^{* *}$ & $.430^{* *}$ \\
\hline & & Sig. (2-tailed) & & & & .000 & .000 \\
\hline & \multirow[t]{2}{*}{$\begin{array}{l}\text { Cognitive } \\
\text { Capital }\end{array}$} & $\begin{array}{l}\text { Correlation } \\
\text { Coefficient }\end{array}$ & & & & & $.442^{* *}$ \\
\hline & & Sig. (2-tailed) & & & & & .000 \\
\hline & \multirow{2}{*}{$\begin{array}{l}\text { Operational } \\
\text { perfor- } \\
\text { mance }\end{array}$} & $\begin{array}{l}\text { Correlation } \\
\text { Coefficient }\end{array}$ & $\begin{array}{l}.491^{* *} \\
.000\end{array}$ & & & & \\
\hline & & Sig. (2-tailed) & & & & & \\
\hline
\end{tabular}

${ }^{* *}$ Correlation is significant at 0.01 (2-tailed).

S o u r c e : developed by authors. 


\section{Regression Analysis of the Variables}

As shown in table $6(\mathrm{a}, \mathrm{b})$, this study tested a multiple linear regression analysis to examine the effect of the social capital dimensions on operational performance development. The three dimensions of the social capital represent R Square. Accordingly, this explains the relational, structural and cognitive capitals for $22.8 \%$ of the operational performance development of commercial banks in Erbil, as shown in the table 6 (a).

Table 6 a. Model Summary ${ }^{b}$

\begin{tabular}{|c|c|c|c|c|}
\hline \hline Model & R & R Square & Adjusted R Square & $\begin{array}{c}\text { Std. Error } \\
\text { of the Estimate }\end{array}$ \\
\hline \hline 1 & $.478^{\mathrm{a}}$ & .228 & .221 & .41819 \\
\hline
\end{tabular}

a. Predictors: (Constant), Social Capital.

b. Dependent Variable: Operational performance.

S o u r c e : developed by authors.

From table 6 (b), we can see that the significance is $\mathrm{p}<0.05$. Thus, the impact of social capital is significant on the operational performance development of the commercial banks in Erbil. At the 0.05, the calculated $F$ was 36.268, and $D F$ 1,109 highlighting that the entire model is significant at $\mathrm{p}<0.05$.

Table 6 b. F Test Significant of the Regression ${ }^{\mathrm{a}}$

\begin{tabular}{|l|l|c|c|c|c|c|}
\hline \hline \multicolumn{2}{|c|}{ Model } & $\begin{array}{c}\text { Sum } \\
\text { of Squares }\end{array}$ & Df & Mean Square & F & Sig. \\
\hline \hline \multirow{2}{*}{1} & Regression & 5.643 & 1 & 5.643 & 36.268 & $.000^{\text {b }}$ \\
\cline { 2 - 7 } & Residual & 19.062 & 109 & .175 & & \\
\cline { 2 - 7 } & Total & 24.705 & 110 & & & \\
\hline
\end{tabular}

a. Dependent Variable: Operational performance.

b. Predictors: (Constant), Social Capital.

S o u r c e : developed by authors. 
Table 6 c. Regression Analysis Coefficients ${ }^{\mathrm{a}}$

\begin{tabular}{|c|c|c|c|c|c|c|c|c|}
\hline \multirow{2}{*}{\multicolumn{2}{|c|}{ Model }} & \multicolumn{2}{|c|}{$\begin{array}{l}\text { Unstandardized } \\
\text { Coefficients }\end{array}$} & \multirow{2}{*}{$\begin{array}{c}\begin{array}{c}\text { Standardi- } \\
\text { zed Coeffi- } \\
\text { cients }\end{array} \\
\text { Beta }\end{array}$} & \multirow{2}{*}{$\mathbf{T}$} & \multirow{2}{*}{ Sig. } & \multicolumn{2}{|c|}{ Collinearity Statistics } \\
\hline & & B & S. Error & & & & Tolerance & VIF \\
\hline \multirow[t]{4}{*}{1} & $\begin{array}{l}\text { (Constant) } \\
\text { Social Capital }\end{array}$ & $\begin{array}{r}2.585 \\
.439\end{array}$ & $\begin{array}{l}.289 \\
.077\end{array}$ & .478 & $\begin{array}{l}8.930 \\
5.680\end{array}$ & $\begin{array}{l}.000 \\
.000\end{array}$ & 1.000 & 1.000 \\
\hline & Relational Capital & .308 & .067 & .404 & 4.615 & .000 & 1.000 & 1.000 \\
\hline & Structural Capital & .347 & .073 & .416 & 4.778 & .000 & 1.000 & 1.000 \\
\hline & Cognitive Capital & .406 & .074 & .464 & 5.464 & .000 & 1.000 & 1.000 \\
\hline
\end{tabular}

a. Dependent Variable: Operational performance.

S o u r c e : developed by authors.

As the results presented in table 6 (c) illustrate, statistically there is a significant impact from the social capital and its dimensions as relational, structural, and cognitive capitals on operational performance development of the commercial banks in Erbil, as defined over an extent of 0.478, 0.404, 0.416 and 0.464 , respectively, and as revealed with a p-value of $0.000,0.000$ and 0.000 , respectively. Besides, the t-test $=(5.680 ; \mathrm{p}<0.05)$ for social capital, which means significant and supporting results, with t equalling 4.615, 4.778 and 5.464, for dimensions as relational, structural, and cognitive capitals, respectively, and $\mathrm{p}<0.05$ for all three dimensions. Then, hypotheses $H_{1} H_{2} \& H_{3}$ are proved.

However, table 6 (c) also displays multicollinearity statistics, which can be seen from the correlation matrix among independent variables on the value of variance inflation factor (VIF).

Therefore, if the VIF value is less than 5 and the tolerance value is above 0.1, it means that there is no multicollinearity among independent variables. From Table 4 (c), the Tolerance values and VIF values for each variable were: 1.000 and 1.000 for social capital, 1.000 and 1.000 for relational capital, and finally the same values 1.000 and 1.000 for structural, and cognitive capitals variables. It means that VIF $<5$ and tolerance value $>0.1$, hence the absence of multicollinearity. 


\section{CONCLUSION, Limitations AND RECOMMENDATIONS}

The purpose of this study is to investigate the effect of social capital dimensions on the operational performance development of the commercial banks in Erbil. The results support the main hypotheses and the objective of the study. Accordingly, the study tested the relationships between social capital dimensions include: (relational capital, structural capital, and cognitive capital) and operational performance development by taking opinions from nominated commercial banks operating in Erbil, the study also verified the impact of social capital on the operational performance development by using (cost performance, quality performance, delivery performance, flexibility performance and innovation performance) based operational performance measures. Supposing that the effect of social capital is an important step before commercial bank's management, it has been an appreciated determination to produce an outline in order to make commercial banks in Erbil conscious of the significance of dealing social capital and investing it in operational performance development.

The study found positive significant relationships between relational, structural, and cognitive capitals with operational performance development. The relational capital and structural capital have more active roles in developing operational performance. Additionally, the regression analysis test results show that, statistically, all social capital dimensions have an effect on operational performance.

Further conclusions in terms of practical implications can be considers as follow; First, it is necessary for commercial banks in Erbil, to develop and invest the relational capital and structural capital based on their significant effect on operational performance, yet, more improve and practice of cognitive capital. Second, since social capital does stimulus operational performance of commercial banks in Erbil, bank's managers require to attention on other boundaries that they intensification their operational performance than social capital dimensions. Last but not lease, the recommendation related commercial banks necessity to develop training programs for their managers, as well as for administrative staff, directing at refining their social capital performs in the positive of the solid role of this variable and its dimensions on banks operational performance development.

It is hoped that the understanding gained from this study, can shed light on these elements of social capital in region of Iraq, Erbil, which has not been addressed within literature so far. In this way, this is an attempt to further 
strengthen activities of various enterprises in this country, and hence be a contribution to the literature on this subject.

As to the limitations, one of the fundamental setbacks was the fact that, of this study the results are based only 25 existed for social capital and operational performance development. As a result, future works should contain more indicators to examine the significance of social capital in these establishments. The study is based on convenience sampling and, hence, its results cannot be generalized. Therefore, secondly, the study can be applied with a larger population. Additionally, the present study took into consideration all three dimensions of social capital. In this respect, future works can focus on only one aspect and, hence, achieve more specific results.

\section{UII REFERENCES}

Andrews, R. (2010). Organizational social capital, structure and performance. Human Relations, 63, 583-608.

Adler, P.S., \& Kwon, S-W. (2002). Social capital: Prospects for a new concept. Academy of Management Review, 27(1) 17-40.

Bessant, J.K. (2003). Putting supply chain learning into practice. International Journal of Operations \& Production Management, 23(2), 167-184.

Bourdieu, P. (1985). The forms of capital. In J.G. Richardson (Ed.). Handbook of theory and research for the sociology of education. New York: Greenwood.

Brett, J. M., Shapiro, D. L., \& Lytle, A. L. (1998). Breaking the bonds of reciprocity in negotiations. Academy of Management Journal, 41, 410-424.

Burt, R.S. (1997). The contingent value of social capital. Administrative Science Quarter$l y, 42(2), 339-365$.

Burt, S.R. (2004). Structural Holes and Good Ideas. American Journal of Sociology, 110(2), 349-399.

Carolis, D.M., Litzky, B.E, \& Eddleston, K.A. (2009).Why Networks Enhance the Progress of New Venture Creation: The Influence of Social Capital and Cognition. Entrepreneurship Theory and Practice, 527-545.

Cary, S.L. (2011). Social Capital Configuration, legal Bonds, and performance in buyerSupplier relationships. Journal of Operations Management, 29(4), 227-288.

Clark, K.F. (1991). Product Development Performance. Boston, MA: Harvard Business School Press.

Coleman, J. S. (1990). Foundations of Social Theory. The Belknap Press Of Harvard.

Cousins, P.R. (2006). Creating supply chain relational capital: The impact of formal and informal socialization processes. Journal of Operations Management, 24(6), 851-863 .

Doz, Y. (1996.) The evolution of cooperation in strategic alliances: initial conditions or learning processes. Strategic Management Journal, 17, 55-83. 
Ferris, S.P., Javakhadze, D., \& Rajkovic, T. (2017). The international effect of managerial social capital on the cost of equity. Journal of Banking and Finance, 74, 69-84.

Fukuyama, F. (1997). Social capital and the modern capitalist economy: Creating a high trust workplace. Stern Business Magazine, 4(1).

Gargiulo, M., \& Benassi, M. (2000). Trapped in Your Own Net? Network Cohesion, Structural Holes, and the Adaptations of Social Capital. Organization Science, 11, 183-196.

Granovetter, M.S. (1992). Problems of explanation in economic sociology. In N. Nohria, R. Eccles (Eds). Networks and Organisations: Structure, form, and action. Boston: Harvard Business School Press.

Gupta, A., Raman, K., \& Shang, C. (2018). Social capital and the cost of equity. Journal of Banking and Finance, 87, 102-117.

Handfield, R.B., \& Nichols, E.L. (1999). Introduction to supply chain management. New York: Prentice Hall Upper Saddle River.

Hatzakis, J., Lycett, M., Macredie, R.D., \& Martin, V.A. (2005). Towards the development of a social capital approach to evaluating change management. European Journal of Information Systems, 14, 60-74.

Helper, S. (1991). Have things really changed between automakers and their suppliers? Sloan Management Review, 32, 15-28.

Hughes, M.P. (2011). Shaping and re-Shaping Social Capital in Buyer-Supplier relationship. Journal of Business Research, 64(2), 164-171.

Inkpen, A.C., \& Tsang, E.W. (2005). Social capital, networks, and knowledge transfer. Academy of Management Review, 30(1), 146-165.

Kale, P., Singh, H., \& Perlmutter, H. (2000). Learning and protection of proprietary assets in strategic alliances: Building relational capital. Strategic management Journal, 21(3), 217-237.

Kleinbaum, A.M., \& Tushman, M.L. (2007). Building bridges: The social structure of interdependent innovation. Strategic Entrepreneurship Journal, 1, 103-122.

Koka, B.P. (2008). Designing alliance networks: the influence of network position, environmental change, and strategy of firm performance. Strategic Management Journal, 29(6), 639-661.

Koufopoulos, D., Zoumbos, V., Argyropoulou, M., \& Motwani, J. (2008). The top management team and corporate performance: a study of Greek firms. Team Performance Management, 14(8), 340-363.

Krause, D.R., Handfield, R.B., \& Tyler, B.B. (2007). The relationships between supplier development, commitment, social capital accumulation and performance improvement. Journal of operations management, 25(2), 528-545.

Lawson, B. (2008). Antecedents and consequences of social capital on buyer performance improvement. Journal of Operations Management, 26 (3), 446-460.

Lee, R. (2017). The Social Capital of Entrepreneurial Newcomers: Bridging, Status-Power and Cognition. Palgrave: McMillan. UK.

Lee, L.L. (2004). Social capital links between management-decision making, intellectual capital and market performance. Online Journal of Management Knowledge, 1 , 45-66. 
Lee, R. (2009). Social capital and business and management: Setting a Research Agenda. International Journal of Management Reviews, 11(3), 247-273.

Li, L., Lin, Z., \& Arya, B. (2008). The turtle-hare race story revisited: Social capital and resource accumulation for firms from emerging economies. Asia Pacific Journal of Management, 25, 251-275.

Lin, N. (1999). Social networks and status attainment. Annual Review of Sociology, 25, 467-487.

Light, I., \& Dana, L.P. (2013). Boundaries of social capital in entrepreneurship. Entrepreneurship Theory and Practice, 37, 603-624.

Manning, P. (2010). Explaining and developing social capital for knowledge management purposes. Journal of Knowledge Management, 14, 83-99.

Maurer, I., Bartsch, V., \& Ebers, M. (2011). The value of intra-organizational social capital: How it fosters knowledge. Organization Studies, 32, 157-185.

Moran, P. (2005). Structural vs. relational embeddedness: social capital and managerial performance. Strategic Management Journal, 26, 1129-1151.

Nahapiet, J., \& Ghoshal, S. (1998). Social capital, intellectual capital, and the organizational advantage. Academy of Management Review, 23(2), 242-266.

Packalen, K.A. (2007). Complementing capital: The role of status, demographic features, and social capital in founding teams' abilities to obtain resources. Entrepreneurship Theory and Practice, 31, 873-891.

Parker, A., Halgin, D.S., \& Borgatti, S.P. (2016). Dynamics of Social Capital: Effects of Performance Feedback on Network Change. Organization Studies, 37(3), 375-397

Parkhe, A. (1993). Strategic alliance structuring: a game theoretic and transaction cost examination of interfirm cooperation. Academy of Management Journal, 36, 794$-829$.

Putnam, R.D. (1995). Tuning in, tuning out: The strange disappearance of social capital in America. Political Science and Politics, 28(4), 664-683.

Reagans, R., \& Zuckerman, E.W. (2001). Network diversity and productivity: the social capital of corporate R\&D teams. Organization Science, 12, 502-517.

Sako, M., \& Helper, S. (1998). Determinants of trust in supplier relations: evidence from the automotive industry in Japan and the United States. Journal of Economic Behavior and Organization, 34(3), 387-417.

Sanders, R. (2008). The pattern of information technology use: the impact on buyer supplier coordination and performance. Journal of Operations Management, 26(3), 349-367.

Seibert, E.S., Kraimer, M.L., \& Liden, R.C. (2001). A Social Capital of Career Success. The Academy of Management Journal, 44(2) 219-237.

Silkoset, R. (2013). Negative and positive effects of social capital on co-located firms. European Journal of Marketing, 47(1/2), 174-197.

Svendsen, G.L.H. (2006). Studying social capital in Situ: a qualitative approach. Theory and Society, 35, 39-70.

Tantardini, M., \& Kroll, A. (2015). The role of organizational social capital in performance management. Public Performance \& Management Review, 39(1), 83-99. 
Totterman, H., \& Sten, J. (2005). Start-ups business incubation and social capital. International Small Business Journal, 23, 487-511.

Tsai, W.P., \& Ghoshal, S. (1998). Social capital and value creation: The role of inter-firm networks. The Academy of Management Journal, 41(4), 464-476.

Ward, P.M. (1998). Competitive priorities in operations management. Decision Sciences, 29(4), 1035-1046. 